scientific community, to advise him on how to develop a more coordinated and responsive research strategy. One recommendation of the council, which met for the first time in September, was that the research minister should have broader responsibilities.

In particular, the council has said it would like the minister to have more control over the total government research budget; at present, responsibility is divided between at least four ministries. It now has the task of suggesting how the desired closer contact between science and industry can become an effective reality.

The creation of the technology council has prompted lobbying from groups keen to see a change in policy. At the end of November, for example, the Christian Democrats published a 22-point proposal for a more strategic allocation of research funds.

This was followed in December by recommendations from the Bundesverband der Deutschen Industrie, German industry's umbrella organization, on topics the technology council should take up to improve strategic thinking about research. Most of the recommendations coincide with the council's own initial conclusions.

The growing interest in science and technology policy has also prompted a parliamentary debate due to take place next week (13 January). Krüger is expected to take the opportunity to insist that, despite previous rumours to the contrary (see Nature 365, $481 ; 1993)$, there will be no shift in the proportion of research ministry funds going to basic research in the near future. German scientists are approaching the new year cautiously, but perhaps with less foreboding than in the recent past.

Alison Abbott

\title{
France shifts the focus from military to civilian technology
}

Paris. Shortly before Christmas, a report to the French government recommended that France give up its autonomy in armaments manufacturing, and share its costs with other European countries.

Such a proposal would have been unthinkable a few years ago; that it is now being seriously considered demonstrates the impact that changes in the world's geopolitical scene have had on French thinking about its technology strategy - and, indirectly, on its support for science.

France ended almost 12 years of unbroken Socialist rule in March 1993 by voting decisively for a conservative government. Over the next few weeks, the government will set about developing a national research strategy through a vast national consultation with a debate in parliament.

Although the new government is taking the credit for this initiative, much of the demand for change has arisen from policies launched by Hubert Curien, the minister of science in the previous Socialist government, and has been prompted by geopolitical adjustments to the end of the Cold War.

These adjustments have in particular removed the justification for much of the research that has assured France's military might, and earned it a disproportionately strong voice at the world negotiating table. As a result, France is having to reshape its research base into a tool for promoting industrial rather than military competitive-

\section{Russian election re-opens old conflicts}

Moscow. Russian science, like much else in the country, enters the new year in a state of turmoil and uncertainty. Much of this results from last month's elections, one of whose immediate effects could be the virtual disappearance of the Ministry of Science, and a decision to return responsibility for basic science to the Russian Academy of Sciences.

During the past year, the ministry has been at the forefront of efforts to reform Russia's scientific system, bringing its practices more in line with those of the West by, for example, encouraging greater competition between researchers and closer links with industry.

Shortly after the elections, however, President Boris Yeltsin announced plans to make drastic cuts in the number of ministries. According to some sources, the Ministry of Science and Technical Policy leads the list.

Closing the ministry was first proposed to the president in September last year in a memorandum by Nikolai Malyshev, his adviser on science and education. Malyshev proposed putting the academy back in charge of all basic research, and merging the Ministry of Science - which he described as functioning in the "oldfashioned" Soviet way - with the Ministry of Education and the State Committee on Higher Education to form a single Ministry of Science and Education.

Ministry officials and their supporters deny Malyshev's charges. They claim that, because of low salaries, the number of staff working in the ministry is actually decreasing. They also reject the criticism that newly-created bodies such as the Russian Foundation of Basic Research waste money in the classic Soviet way.

Academy officials argue that the organization needs to be given new authority to restore the fortunes of Russian science. Its critics claim that such a move would, in practice, do the opposite. The debate is guaranteed to intensify in 1994.

Vladimir Pokrovsky ness, swapping its military goals for a desire to protect and exploit its strengths in such areas as computer software, biotechnology and the audiovisual sector.

Change in 1994 will also focus on longstanding structural problems in the research and university system and will be intended to stimulate the productivity of the science base. Current problems include poor coordination of national research policy, and lack of mobility of scientists both within the research organizations and between the universities and industry.

The national consultation is unlikely to bring much radical new thinking to these problems. But, like the ensuing parliamentary debate, it should help to crystallize potential solutions, and stimulate public awareness of the importance of research to the economy.

The most likely outcome will be an enhanced trend towards more strategic research, achieved not by simply increasing support for applied science, but by making basic research and technology-transfer more directed and efficient.

Basic science will receive some protection merely because almost all French researchers are civil servants on whom the government is reluctant to impose job reductions. Nonetheless, observers predict that areas of long-term basic research will probably stagnate.

On the ground, 1994 will see a big increase in the number of small mixed laboratories bringing together industry and government-funded scientists. The FFr 1.6 billion (US\$270 million) government-backed biotechnology programme, BioAvenir, that links Rhone-Poulenc with a clutch of public laboratories, is likely to become a model for close cooperation between industry and public science (a similar programme for chemistry, ChemiAvenir, is already on the cards).

Intriguingly for a government pledged to loosen the state controls of its predecessor, the task of ensuring that industrial competitiveness becomes a priority for the whole research system will be achieved in 1994 by stronger central control of strategy. The Centre National de la Recherche Scientifique (CNRS), for example, is due to sign the first of the new five-year contracts under which the ministry and research organizations aim to agree on fixed objectives and the means to achieve them (see Nature 365, 598; 1993).

François Kourilsky, the director general of CNRS and a Socialist supporter, steps down in June. CNRS management will probably replace him by someone more sympathetic to the government's aims, and more radical reforms may follow.

Declan Butler 